\title{
Individual endoscopic management of anastomotic insufficiency after esophag- ectomy for esophageal squamous cell carcinoma and creation of a neostomach
}

A 57-year-old patient with a T3, cN0, G2, M0 esophageal squamous cell cancer received neoadjuvant radiochemotherapy according to the CROSS trial. After successful esophagectomy and consecutive gastroesophageal anastomosis, the patient recovered appropriately. Unfortunately, the patient developed circular anastomotic insufficiency with two cavities at Day 7 ( Fig. 1). One of the cavities arose from the circular insufficiency $(2 \times 2 \mathrm{~cm})$, and the other was formed by a stapler insufficiency of the stomach $(3 \times 2 \mathrm{~cm})$. The final tumor stage was histologically proven to be ypT0, N0, cM0, LO, V0, RO.

We started repetitive endoluminal vacuum therapy (Endo-Sponge; B. Braun, Melsungen, Germany) for a treatment period of 2 months ( $\triangleright$ Video 1 ). Owing to the remarkable dimension of the cavities, we decided initially to place two devices per insufficiency ( $>$ Fig.2), and in total, 11 device replacements were performed. After 2 weeks of treatment, the use of one Endo-Sponge appeared to be sufficient to cover all areas of insufficiency. A negative intracavital pressure was applied $(15-20 \mathrm{mmHg})$ in order to avoid the development of pulmonary fistula. Antibiotic and antifungal treatment was also administered during the first 2 weeks of the vacuum therapy. The patient received parenteral nutrition but was allowed to drink liquids during the treatment period ( $\triangleright$ Fig. $\mathbf{3}$ ).

Unfortunately, despite appropriate endoscopic procedures and frequent Endo-Sponge exchange, the insufficiencies failed to heal and the cavities persisted. Therefore, a more aggressive endoscopic therapeutic approach was initiated ( $>$ Video 1 ). We utilized cytological brushes and argon plasma coagulation at the edges of cavital insufficiencies in order to induce vascular spreading and wound granulation (\$Fig.4). Fibrotic tissue and surgical staple sutures were endoscopically removed using cutting

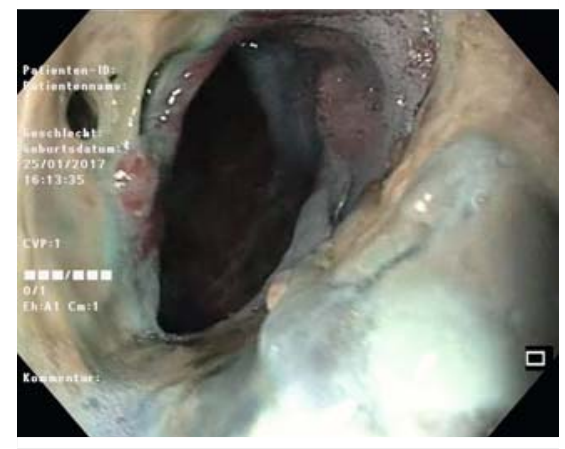

- Fig. 1 Superior part of anastomotic insufficiency at $25 \mathrm{~cm}$ from the upper dental arch.

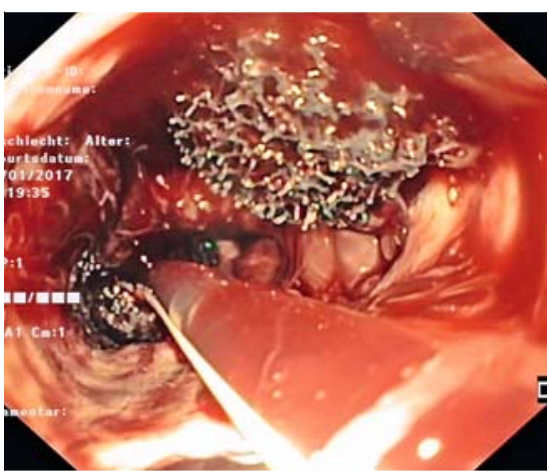

- Fig. 2 Placement of two Endo-Sponge devices (B. Braun, Melsungen, Germany) into the two cavities.

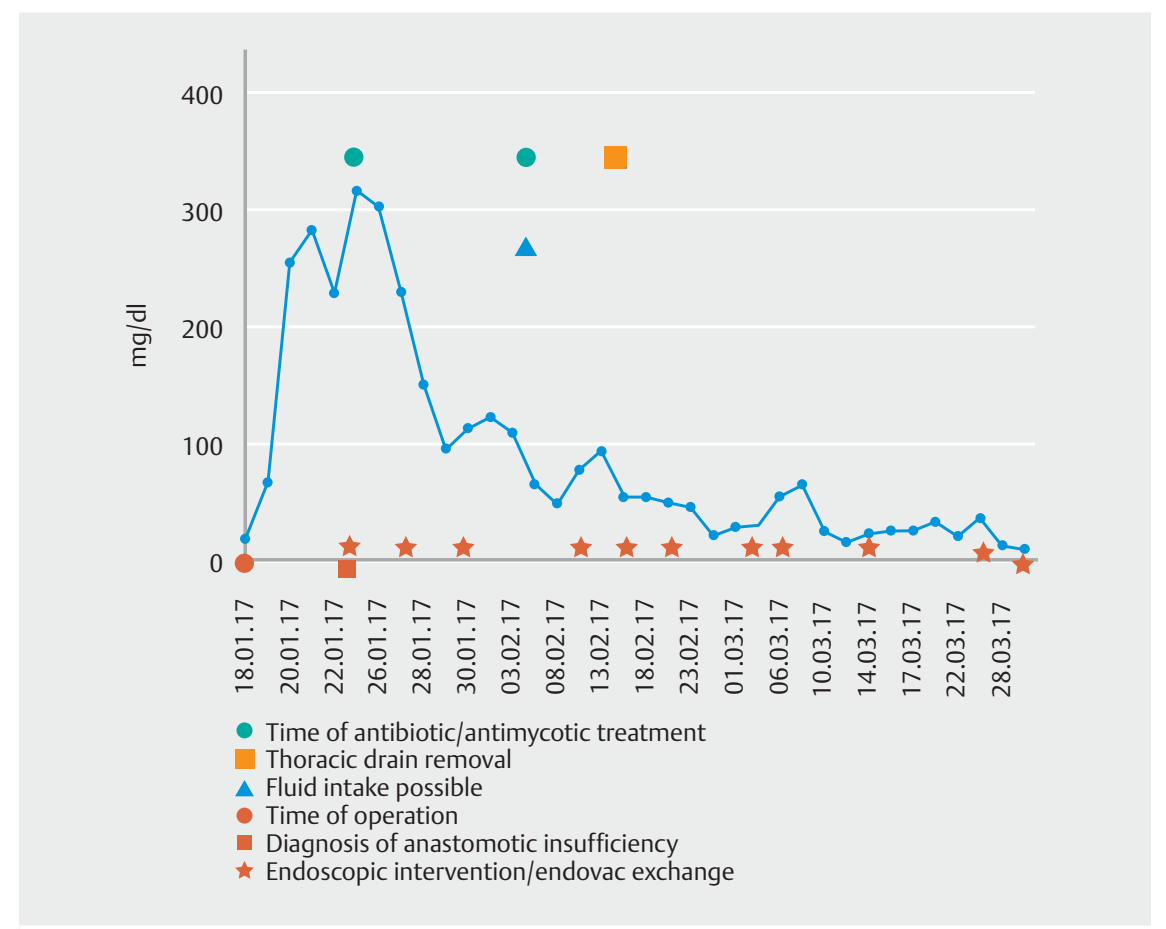

- Fig. 3 Overview of the clinical course of the patient in correlation with progression of C-reactive protein levels and endoscopic intervention.

devices and graspers. Mucosal bridges were cut by needle-knife incision, leading to development of a neostomach and esophagogastric continuity. In addition, epithelial mucosa spreading occurred, evolving from the upper esophageal tissue.
After 2 months of endoscopic treatment, neither fistula nor anastomotic insufficiencies were detectable. In addition, a neostomach had been created, consisting of mediastinal parietal pleura, the distal esophagus, and the remnant stom- 

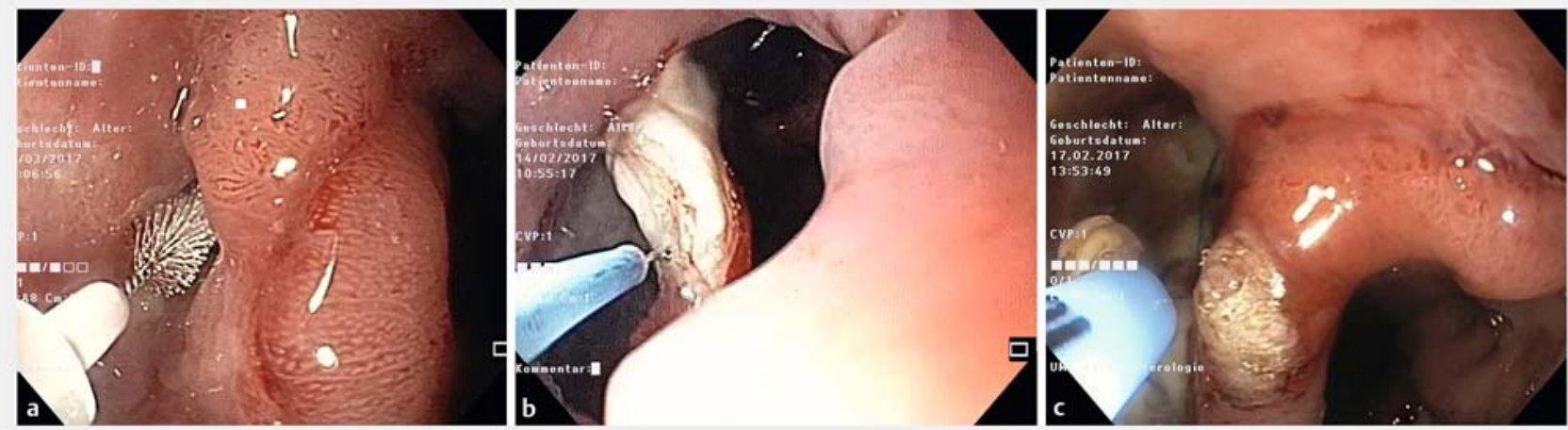

- Fig. 4 Endoscopic therapy for persistent anastomotic insufficiency: a brushing to induce wound granulation; b fibrotic tissue removal with a needle-knife; $c$ argon plasma coagulation to induce vascularization.
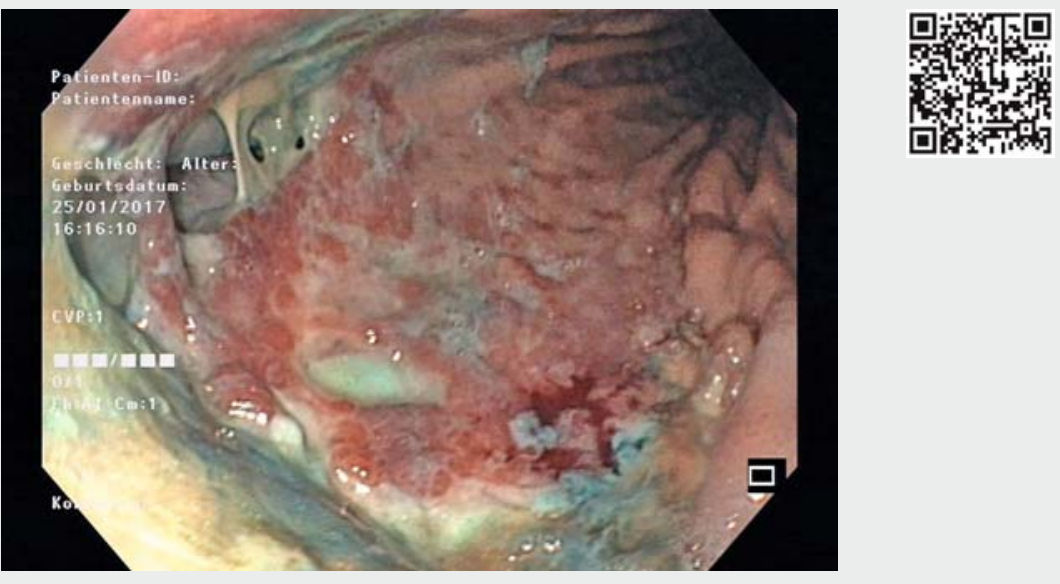

$\nabla$ Video 1 Endoscopic treatment of anastomotic insufficiency after esophagectomy for esophageal squamous cell carcinoma over a period of 2 months.

ach ( $\mathbf{F i g . 5 )}$. Continuity was proven by barium swallow.

Endoluminal vacuum therapy and esophageal stenting are established treatment options sfor anastomotic insufficiencies following esophageal resection [1,2]. Whether stent placement is superior to vacuum therapy remains to be discussed, but preliminary data are in favor of vacuum therapy $[3,4]$.

Endoscopy_UCTN_Code_CPL_1AM_2AF

Competing interests
The authors

Edris Wedi ${ }^{1}$, Philipp Schüler ${ }^{2}$, Steffen Kunsch ${ }^{1}$, B. Micheal Ghadimi ${ }^{2}$, Ali Seif Amir Hosseini $^{3}$, Volker Ellenrieder ${ }^{1}$, Carlo Jung ${ }^{1}$

1 Department of Gastroenterology and Gastrointestinal Oncology, Center of Interdisciplinary Endoscopy, University Medical Center Göttingen, Göttingen, Germany

2 Department of General Visceral and Paediatric Surgery, University Medical Center, Göttingen, Germany

3 Department of Diagnostic and Interventional Radiology, University Medical Center Göttingen, Germany

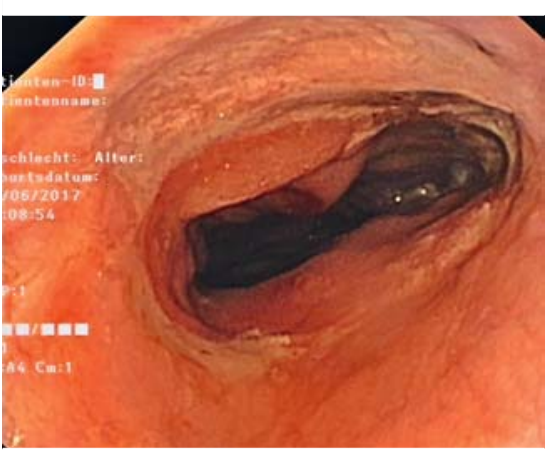

- Fig. 5 Creation of a neostomach after endoscopic treatment.

Corresponding author

\section{Edris Wedi, MD}

Department of Gastroenterology and Gastrointestinal Oncology, Center of Interdisciplinary Endoscopy, University Medical Center Goettingen, Georg-AugustUniversity, D-37075 Goettingen, Germany Fax: +49-512-1901241

edris.wedi@med.uni-goettingen.de

None 


\section{References}

[1] Weidenhagen R, Hartl WH, Gruetzner KU et al. Anastomotic leakage after esophageal resection: new treatment options by endoluminal vacuum therapy. Ann Thorac Surg 2010; 90: 1674-1681

[2] Licht E, Markowitz A], Bains MS et al. Endoscopic management of esophageal anastomotic leaks after surgery for malignant disease. Ann Thorac Surg 2016; 101: 301 - 304

[3] Mennigen R, Harting C, Lindner K et al. Comparison of endoscopic vacuum therapy versus stent for anastomotic leak after esophagectomy. J Gastrointest Surg 2015; 19: $1229-1235$
[4] Brangewitz M, Voigtlander T, Helfritz FA et al. Endoscopic closure of esophageal intrathoracic leaks: stent versus endoscopic vacuum-assisted closure, a retrospective analysis. Endoscopy 2013; 45: 433-438

\section{Bibliography}

DOI https://doi.org/10.1055/s-0043-124180

Published online: 12.1.2018

Endoscopy 2018; 50: E69-E71

(c) Georg Thieme Verlag KG

Stuttgart · New York

ISSN 0013-726X

\section{ENDOSCOPY E-VIDEOS}

https://eref.thieme.de/e-videos

回回 Endoscopy E-Videos is a free Fection, reporting 回舴: on interesting cases and new techniques in gastroenterological endoscopy. All papers include a high quality video and all contributions are freely accessible online.

This section has its own submission website at

https://mc.manuscriptcentral.com/e-videos 